Marc AMMERICH

Jean-Christophe BODINEAU

Hugues BRUCHET
Advanced Technician in Radiation Protection, CNAM engineer in nuclear physics and holds a Master in Aerosols Science. After beginning his career in the Department of Radiological Protection at the CEA, Saclay, he joined the radiation protection team of the INSTN in 1991 and became its manager in 1996. Working at the French Nuclear Safety Authority (ASN) in 2001, he is a confirmed inspector in radiation protection. After having joined the direction of Protection and Nuclear Safety of the CEA in 2006, he has served as a nuclear inspector at the CEA since 2008. He is also a lecturer at the INSTN and communicating-researcher. He received the SFEN award in 1989 for the realization of ICARE bench.

holds a BTS in Radiation Protection, he began his career at the CEA by monitoring the X-ray generators, particle accelerators and radiation sources used in research and industry. This experience has allowed him to teach the practice of radiation protection. He became an engineer in nuclear science and technology and he began to teach radioactivity, interaction and radiation detection at the INSTN. After obtaining a Master in Applied Physics, he became responsible for teaching in the institute. He specializes in teaching the detection of ionising radiation, a field in which he is recognized as a senior expert at the CEA. An important part of his activities for the training of doctors and nurses of the French nuclear power plants in the field of anthropogammametry.

obtained his master's degree in 2001 (DESS Radioprotection, University of Grenoble). Currently he is an engineer at the CEA (French Atomic Energy and alternative energies Commission) and deputy head of the teaching unit "Health Technologies and Radiation Protection" at the INSTN (National Institute for Nuclear Science and Technology part of the CEA). Moreover, he is involved in teaching the "Personnes compétentes en radioprotection (PCR)" as a certified teacher, author and coordinator of books in the field of radiation protection, and member of PCR teachers certification comitee (CEFRI). 
Cécile ETARD

\section{Christine JIMONET}

\section{Philippe MASSIOT}

\section{Henri MÉTIVIER}

Jean-Claude MOREAU
Medical physicist. After 2 years in a radiotherapy department, Cecile Etard joined the Central Laboratory for Electrical Industries where she practiced for six years as an engineer in the metrology of ionising radiation. She joined the INSTN in 2000 as head teacher and trainer of several lessons in the field of radiation protection and medical physics. In 2003, she undertook the responsibility of the INSTN Radiation Protection team. In 2007, she joined the Unit of Expertise in Medical Radiation Institute for Radiological Protection and Nuclear Safety (IRSN).

$\mathrm{PhD}$ in Biochemistry, graduated from the University of Paris $\mathrm{XI}$, she is in charge of the unit "Technology for Health and Radiation Protection" within the National Institute for Nuclear Sciences and Techniques (INSTN) at the CEA. More specifically she taught the topic "Biological effects of ionising radiations" in various training courses. At the INSTN, she is also the manager of education related to the medical internship in Nuclear Medicine.

CNAM Engineer in Nuclear Science and Technology, Philippe Massiot began as a researcher at the CEA of particle accelerators in the field of materials and radiobiology. He then specialized in radio toxicology of actinides. After 5 years spent in the French Nuclear Safety Authority (ASN) as training manager and radiation protection inspector, he is now responsible for teaching Radiation Protection and involved in a European project to harmonize regulatory training in radiation protection. He is also an expert at the CEA.

$\mathrm{PhD}$, is a former Research Director at the CEA. Former member of the ICRP, Professor Emeritus at the INSTN, Chairman of "Comité de rédaction de la revue Radioprotection", Journal of the French Society for Radiation Protection, Chairman of the Drafting Committee for Radiation Protection. He is the author and coordinator of numerous books in the field of radiation protection and also plutonium.

Radiation Protection Technician, Engineer CNAM in Physics, he worked in radiation at CEA/Saclay for 16 years and held leadership positions at STMI (Areva group). After a brief detour in environmental technology, in 2000 he founded the company CAP $2 \mathrm{i}$, a firm specializing in radiation protection studies, expertise and training. He has taught radiation at the INSTN, in several universities and trained many "Personnes compétentes en radioprotection (PCR)". 
Abdel-Mijd NOURREDINE

Hervé VIGUIER

Alain VIVIER
PhD in Physical Sciences and Professor at the University Louis Pasteur of Strasbourg I. He operates a multidisciplinary research institute Hubert-Curien (IPHC), where he leads the leadership team Radiation and Environmental Measures (RaMsEs). Specialist in subatomic physics and nuclear applications, he has a rich experience in Education and PCR training. He has supervised several $\mathrm{PhD}$ thesis on $\mathrm{R} \& \mathrm{D}$ in nuclear instrumentation and dosimetry of ionising radiation.

CNAM Engineer in Nuclear Science and Technology, Hervé Viguier is a research engineer at the French Atomic Energy Commission and alternative energies. He is a training officer and trainer in the field of radioactivity, radiation protection and detection of ionising radiation. $\mathrm{He}$ is also in charge of different practical work of various engineering courses.

Engineering School of the Air and engineer in nuclear engineering with weapons option. After several years operating in the unit of nuclear weapon systems on the Plateau d'Albion, he taught physics and nuclear measurement at the School of Military Applications of Atomic Energy (EAMEA). He joined the CEA as head of the radiation protection group assigned to the Plutonium team in Cadarache. He then joined the INSTN Saclay where he set up a training session on ionising radiation dosimetry, among others. 